表 4.9月 24 日, 25 日のメニュー

\begin{tabular}{ll}
\hline \hline \multicolumn{1}{c}{9 月 24} & \multicolumn{1}{c}{9 月 25 日 } \\
\hline 牛肉のカレー炒め煮 & チキンマリネ \\
きゅうり & 野菜スープ \\
キャベッ & ご飯 \\
あやしのごまあえ & 牛乳 \\
ご飯 & みかん \\
垺 & \\
ミックスナッッ & \\
\hline
\end{tabular}

と考えられる. そのため各学校での欠席者数は通常の欠 席者数の変動範囲内之考えられ異常に気づかず, 患者が 集中した $\mathrm{A}$ 病院からの通報を受けた時は，患者発生か
らすでに 6 日経過しており，原因食品，污染経路の解明 が困難となった。

教育委員会での各学校の欠席者などの迅速な把握と対 応が今後の課題として残った。

今回，污染源を明確にすることはできなかったが，原 材料の污染, 調理後の二次污染があったと推定されるこ とから, 集団給食従事者に対し食品の衛生的取扱いの基 本の再確認を図る必要を感じた。

\section{6. 事件処理のためにとった措置}

10 月 3 日，4 日が土，日曜日にあたったため，10月 5 日(月）から 9 日(金)まで業務自肃とした.

（愛知県豊橋保健所 鈴木義教）

\title{
仕出し弁当による黄色ブドウ球菌食中毒
}

\section{1. 亭件の概要}

発生年月日 平成 4 年 10 月 1 日

発生場 所 奈良県御所市 $\mathrm{G}$ 中学校

摄食者数 687 名

患者 数 194 名

死 者 数 0 名

原因食品仕出し弁当（ゆで卯）

病因物質 黄色ブドウ球菌 コ型 VII AB 型

原因施設仕出し屋

2. 真件の探知

平成 4 年 10 月 1 日 16 時頃， $G$ 消防署より救急車で
食中毒症状を呈した $\mathrm{G}$ 中学校の生徒を病院へ収容した こと, 同中学校では当日体育会がありいずれの患者も仕 出し弁当を摃食していた旨の電話連絡により探知した.

\section{3. 患者の発生状況及ひ症状}

$\mathrm{G}$ 中学校で，昼食に仕出し業者か調製したにぎり弁当 を摄食した生徒及び教職員及び保護者など計 687 名中 194 名が発症し, 初発病は当日 13 時頃で翌日正午まで 続いた，生徒は体力を消耗していたためか, 症状は比較 的重く, 吐気及び嘔吐が多く腹痛を伴い下㢉, 発熱等も みられた。体育大会は 105 名の生徒が救急車で搬送され たため，最後までは実施できなかった，発病率は，

表 1. 性別, 年齢別患者数

\begin{tabular}{|c|c|c|c|c|c|c|c|c|}
\hline \multirow{2}{*}{ 性 別 } & \multicolumn{4}{|c|}{ 年 } & & \multirow{2}{*}{ 総 数 } \\
\hline & $10 \sim 14$ & $15 \sim 19$ & $20 \sim 29$ & $30 \sim 39$ & $40 \sim 49$ & $50 \sim 59$ & $60 \sim 69$ & \\
\hline 男 & 67 & 11 & 2 & & 1 & 1 & 1 & 83 \\
\hline 女 & 82 & 14 & 4 & 2 & 8 & 1 & & 111 \\
\hline
\end{tabular}

表 2. 潜伏時間の状況

\begin{tabular}{cccccccccccccccc}
\hline \hline 潜伏時間 & 1 & 2 & 3 & 4 & 5 & 6 & 7 & 8 & 9 & 10 & 14 & 20 & 21 & 24 & 不明 \\
\hline 発病者数 & 10 & 30 & 43 & 52 & 19 & 19 & 7 & 3 & 3 & 2 & 1 & 1 & 1 & 1 & 2 \\
\hline
\end{tabular}

表 3. 症状

\begin{tabular}{lccccccccc}
\hline \hline \multicolumn{1}{c}{ 症 状 } & 腹 痛 & 下 㢉 & 嘔 吐 & 吐 気 & 発 熱 & 頭 痛 & 僚怠感 & 卧 床 \\
\hline 人 数 & 134 & 77 & 88 & 151 & 87 & 86 & 128 & 117 \\
\hline 発現率(\%) & 69.1 & 39.7 & 45.4 & 77.8 & 44.8 & 44.3 & 66.0 & 60.3 \\
\hline
\end{tabular}


表 4. 下㢉及び嘔吐の回数

\begin{tabular}{cccccccccccc}
\hline \hline 1 日の回数 & 1 & 2 & 3 & 4 & 5 & 6 & 7 & 8 & 10 & 15 & 不明 \\
\hline 下利患者数 & 12 & 19 & 20 & 5 & 3 & 2 & 0 & 1 & 4 & 1 & 10 \\
\hline 嘔吐患者数 & 27 & 13 & 10 & 5 & 5 & 11 & 1 & 0 & 6 & 0 & 10 \\
\hline
\end{tabular}

表 5. 発熱

\begin{tabular}{ccccccccc}
\hline \hline 体温 $\left({ }^{\circ} \mathrm{C}\right)$ & 37 未満 & $37.0 \sim 37.4$ & $37.5 \sim 37.9$ & $38.0 \sim 38.4$ & $38.5 \sim 38.9$ & $39.0 \sim 39.9$ & 不 明 \\
\hline 患 者 数 & 33 & 12 & 12 & 12 & 2 & 3 & 13 \\
\hline
\end{tabular}

表 6. 黄色ブドウ球菌（コアグラーゼ産生）検出状 況

\begin{tabular}{cccc}
\hline 検 体名 & '検体数 & 検出数 \\
\hline 患 者 ふ ん 便 & 9 & 9 \\
従事者ふん便 & 9 & 2 \\
従 事 者 手 指 & 7 & 7 \\
施 設, 器 & 具 & 3 & 3 \\
食 品 残 & 品 & 8 & 8 \\
\hline
\end{tabular}

$28.2 \%$, 潜伏時間の平均は, 4 時間 12 分, 下峲は，ほ之 んどの者が水様性で, 1 日の平均下㓱回数, 平均嘔吐回 数は共に約 3 回であった（表 1〜表 5).

\section{4. 摄食状況}

平成 4 年 10 月 1 日体有大会潤かれ，生徒，教職員 及び保護者等が昼食に業者の調理した弁当を摃食した。 従ってこの弁当による食中毒を疑って調查を開始した。 仕出し弁当のメニューは，わかめおにぎり，しそおにぎ り，五目おにぎり，ゆで卵，昆布煮(調理済み食品)，エ ビフライ、クリームコロッケ，たくあん，オレンジ，こ んにゃく，牛乳などで，こんにゃく及びゅで卵などの煮 物類は前日に調製され，こんにゃくは，ゆでて，煮込み 保管され，特に污染の機会は少なかったと思われる。ゅ で卵は，前日の 14 時頃から調理され，ゆで，殼を剝き， 煮込み, 卵きりで半分に切り, 冷蔵庫に保管したが,こ の際に手から污染された可能性がある. 翌朝 5 時から盛 り付けを開始した煮物類以外のものは, 当日の朝 3 時か ら調製して盛り付けを行ったが，多仙のためその際十分 放冷できず 8 時 30 分に盛り付けを終了した．9 時に配 送後，常温に保管され，12 時に摄食した. なお当日の最 高気温は $25.0^{\circ}$, 最低気温は, $16.1^{\circ}$ であった。

\section{5. 原因食品及ひ病因物復 \\ (1) 原因食品}

体育大会当日の昼食は業者から提供された仕出し弁当 で，生徒による飲食物の持ち込みはなかったこと，欠席 した生徒に発症者がいなかったことから, 原因食品は,
仕出し弁当と推定した。 なかでも，発症者におけるゆで 卵の摂食率は, $\chi^{2}$ テストの結果 $\left(\chi^{2}=34.1\right)$ から他の食品 に比べて非常に高かった.

(2) 病因物質

食品の残品, 器具及び従業員の手指のふき取り, 患者 及び従業員の便の各試料から食中毒菌の検索を試みた。 すべての検体から黄色ブドウ球菌（コアグラーゼVII 型）が検出された（表 6). 黄色ブドウ球菌数は，ゆで卵 が最も多く $1.7 \times 10^{8} / \mathrm{g}$ ，おにぎり $2.4 \times 10^{4} \sim 2.0 \times 10^{6} /$ $\mathrm{g}$, 他の食品 $10^{6} / \mathrm{g}$ 以上であった。 エンテロトキシンの 検查ではすべての検体分離株から $\mathrm{AB}$ 型毒素が検出され た，その他の食中毒菌（腸炎ビブリオ，サルモネラ，セ レウス菌, 病原大腸菌）は, 不検出であった。

\section{6. 事件処理のためにとった措置}

平成 4 年 10 月 2 日から同月 8 日までの 7 日間営業停 止を命じ, 始末書を徵収した。 その間, 再発防止対策を 行わせると共に改善内容について指導を行った。

\section{7. 考察及びまめ}

疫学調查及び細菌学的検查により原因食品は, 仕出し 弁当（ゆで卯）と判明した。ゆで卵は，調理過程で素手 で扱う機会が多かった．調理人の手指は，外見上化晨傷 や皮唐疾患等は見られなかったが、少し手あれの状態で ありそれに伴い食品が污染され, 黄色ブドウ球菌の增殖 に伴うエンテロトキシンの産生により, 本件が発生した 可能性が考えられる。 また, 他の発生要因として, (1)業 者は当日本件以外に他からも注文があり，仙しさから副 食の煮炊きものを前日に調理し冷蔵保存した。すなわ ち，営業者の冷蔵庫に対する過信と大量保管による冷却 機能低下，保管中における食品間の相互污染などが起っ た可能性，(2)施設及び従事者の数等から考え，能力を越 えた注文を受けたため，盛り付け前に十分放冷されてい なかったこと，(3)調製から捸食までの時間を配虑しなか ったことなどが挙げられる。

今後営業者は調理能力を正確に把握し, 食品や施設に おける衛生管理及び従業者に対する衛生教育の周知徹底 をはかることが必要である。本件は調理従事者に対して 
手指等の清潔, 消毒の励行をはじめ食品衛生に関する基 本原則を厳守させることの重要性を再認識させられた事 件である。
本件を教訓として業者に対する監視指導の強化など， 行政対応の在り方についても，更に検討を深めたい。

（奈良県葛城保健所 鈴木 清）

\section{結婚式場の料理による腸炎ビブリオ食中毒}

\section{1. 事件の概要}

発生年月日

平成 4 年 10 月 5 日

発生場所

摂食者数

和歌山市湊通り

患 者 数

582 名

死 者 数

原因食品

病因物質

原因施設

\section{2. 衰件の探知}

平成 4 年 10 月 5 日, 大阪府西宮市内の某内科・外科 病院の医師から，下痢，腹痛，嘔吐などの食中毒症状を 訴えている患者を診察した旨の届出が, 県生活衛生課を 通じて保健所管理課に連絡があった。

\section{3. 患者の発生状況及び症状など}

本件は 10 月 4 日, 上記施設において, 10 組の結婚式 が行われ, 出席者 582 名中, 181 名が発症したものであ る.

患者の内訳は，男性 89 名，女性 92 名で発病者は 10 月 5 日，午前 2 時頃からみられ，最も多かったのは 10 月 5 日午前 3 時頃から午後 1 時頃にかけてであった。

潜伏時間は 9 時間加ら 24 時間が最も多く（表 1), 症 状は下㢉, 腹痛, 吐気, 発熱の順であった（表 2).

\section{4. 原因食品の污染経路}

患者 181 名が共通に喫食したものは結婚式の会席料 理（表 3 の 4 種）のみであり,これが原因と考えられた. メニューの中のマグロの刺身から腸炎ビブリオを検出し た．従業員の便からも腸炎ビブリオを検出したが，施設 内のふき取り検查では，本原因菌を検出出来なかった．

\section{5. 病因物質}

施設内の酎房におったマグロの刺身の残品及び舫者, 従業員の便から腸炎ビブリオを検出し, 更に潜伏時間及 び主たる症状を考えあわせ腸炎ビブリオを病因物質之決 定した。

\section{6. 考 察}

今回の食中毒事件は，マグロと患者の便から腸炎ビブ リオが検出されたことから，マグロを食中毒の推定食 品, 腸炎ビブリオを病因物質とする食中毒と断定した。

污染経路については，マグロの仕入れ先に当該品か残 されていなかったことから究明はできなかった。

又，会席料理の共通食品であるマグロを喫食していな い患者が食中毒を引き起こしていたが，この理由として 以下の 2 点が考えられる.

(1)会席料理に出された刺身類をすべて同じ包丁で処理 していたことにより，マグロ以外の魚の刺身にも二次污 染を引き起こした可能性が高いこと.

(2)温度管理を厳格に行うべき生食用鲜魚介類の処理場

表 1. 潜伏時間別患者発症数

\begin{tabular}{lllllllllllllll}
\hline \hline 潜伏時間 & 0 & 3 & 6 & 9 & 12 & 15 & 18 & 21 & 24 & 27 & 30 & 33 & 36 & \\
& 3 & 5 & $\int$ & $\int$ & $\int$ & $\int$ & $\int$ & $\int$ & $\int$ & $\int$ & $\int$ & $j$ & $j$ & 計 \\
& 3 & 6 & 12 & 15 & 18 & 21 & 24 & 27 & 30 & 33 & 36 & & \\
\hline 患者数 & 0 & 1 & 4 & 11 & 24 & 49 & 40 & 18 & 5 & 9 & 6 & 1 & 13 & 181 \\
\hline
\end{tabular}

表 2. 症状

\begin{tabular}{|c|c|c|c|c|c|c|c|c|c|c|c|c|c|c|}
\hline & 下 & 嘔 & 発 & 悪 & 戦 & $\begin{array}{l}\text { 腹 } \\
\text { 痛 }\end{array}$ & $\begin{array}{l}\text { 頭 } \\
\text { 痛 }\end{array}$ & $\begin{array}{l}\text { 裏 } \\
\text { 急 } \\
\text { 後 }\end{array}$ & $\begin{array}{l}\text { 吐 } \\
\text { 気 }\end{array}$ & $\begin{array}{l}\text { 僚 } \\
\text { 怠 } \\
\text { 感 }\end{array}$ & $\begin{array}{l}\text { 脱 } \\
\text { 力 } \\
\text { 感 }\end{array}$ & $\begin{array}{l}\text { 眠 } \\
\text { 症 } \\
\text { 状 }\end{array}$ & $\begin{array}{l}\text { 暖 } \\
\text { 気 }\end{array}$ & 計 \\
\hline 患者数(人) & 162 & 47 & 60 & 70 & 17 & 133 & 44 & 19 & 70 & 50 & 40 & 3 & 15 & 163 \\
\hline 発現率(\%) & 89.5 & 2.6 & 33.1 & 38.7 & 9.4 & 73.5 & 24.3 & 10.5 & 38.7 & 27.6 & 22.1 & 1.6 & 8.3 & \\
\hline
\end{tabular}

